Review Article

\title{
A Review of the Geology of the Rio Del Rey Basin, Offshore Cameroon
}

\author{
Boris B Bate*, Maduka Bertram Ozumba, Edwin Ayuk Ndip and Dorcas S Eyinla \\ Petroleum Geoscience Unit, Department of Geoscience, Institute of Life and Earth Science, Pan African University, University of Ibadan, \\ Ibadan, Nigeria
}

\begin{abstract}
A review of the tectonic evolution, stratigraphic and structural framework, petroleum systems and hydrocarbon potential of the offshore portion of Rio Del Rey (RDR) Basin in Cameroon is presented in this paper. The RDR basin is a passive margin basin present in the Gulf of Guinea and it is located southeast of Niger Delta over an area of about $7,000 \mathrm{~km}^{2}$ offshore. Its stratigraphic components, like those of Niger Delta, comprise of a diachronous succession of prodelta shales (Akata Formation), overlain by delta front sands and shales (Agbada Formation), in turn, overlain by fluvial sands (Benin Formation). The age of this basin ranges from Eocene to Recent and it consists of four structural provinces namely; the growth fault province in the north, the Cretaceous Onshore province in the southeast, the Shale Ridge province in the southwest, and the Delta Toe-thrust in the south-central region. The RDR Basin features three stages of tectonic development: Pre-rift phase (Late Proterozoic to Late Jurassic); Syn-rift phase (Late Jurassic to Early Cretaceous) and Post-rift phase (Late Cretaceous to Holocene). It presently stands out as the major contributor of the petroleum in the country.
\end{abstract}

Keywords: Tectonic evolution; Stratigraphic framework; Hydrocarbon potential; RDR basin

\section{INTRODUCTION}

The sedimentary basins in Cameroon have been classified into two namely; coastal and continental basins [1]. The coastal basins are the Douala/Kribi-Campo and the Rio Del Rey Basins. These are passive margin basins formed in the Cenozoic following the opening of the South Atlantic Ocean when the Gondwana supercontinent broke up in the Late Jurassic. They were filled with sedimentary rocks of predominantly marine origin [2].

The RDR Basin (Figure 1), is one of the coastal basins in the southwest region of Cameroon and represents the southeastern portion of the Niger Delta in the Gulf of Guinea [3-7]. This basin is located between latitude $4^{\circ}$ and $5^{\circ}$ north and longitude $8^{\circ} 20^{\prime}$ and $9^{\circ} 10^{\prime}$ east (Figure 2).

The offshore portion of RDR Basin (which is approximately $7000 \mathrm{~km}^{2}$ ) represents one of the major petroliferous regions of Cameroon [8]. It is bordered by Niger Delta Basin of Nigeria to the west and northwest, and by Rio Muni Basin of Equatorial Guinea to the south. To the north, by the Rumpi Hills and to the east by the Cameroon volcanic line that separates RDR basin from the Douala/Kribi Campo Basin [7].

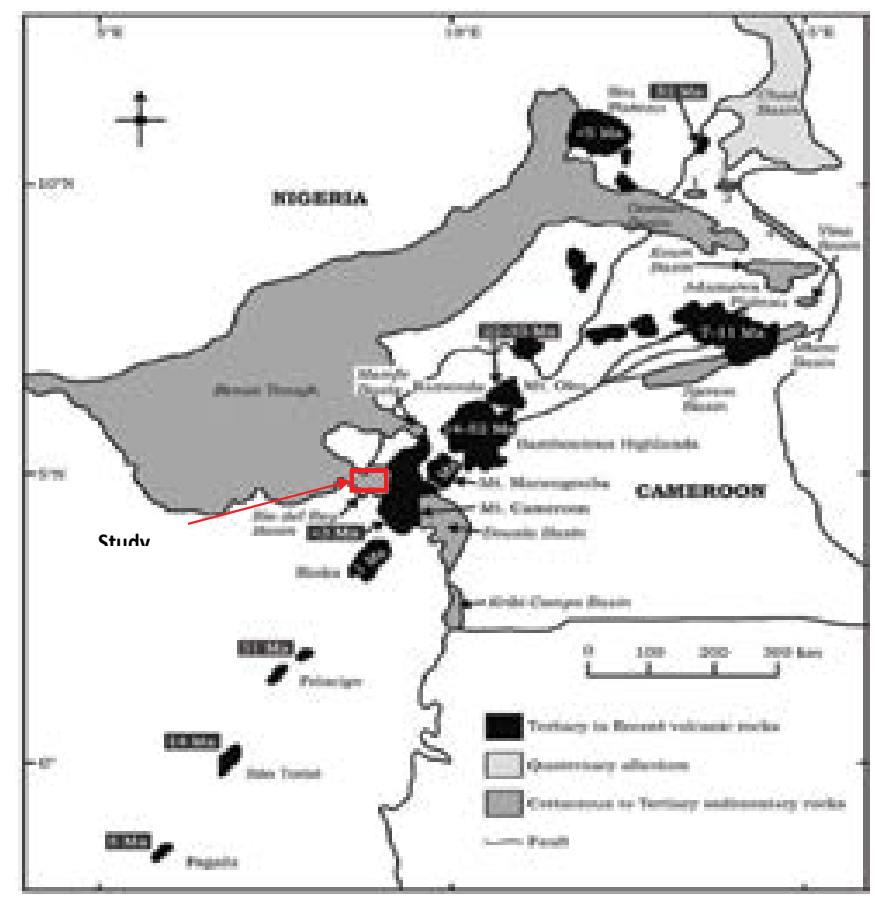

Figure 1: Map of Cameroon outlining the Cameroon Volcanic Line (with volcano ages) and the sedimentary basins [3-5].

Correspondence to: Boris B Bate, Petroleum Geoscience Unit, Department of Geoscience, Institute of Life and Earth Science, Pan African University, University of Ibadan, Ibadan, Nigeria, Tel: +2348032773639; E-mail: borisyasonbate@gmail.com

Received: January 14, 2019, Accepted: February 19, 2019, Published: February 26, 2019

Citation: Bate BB, Ozumba MB, Ndip EA, Eyinla DS (2019) A Review of the Geology of the Rio Del Rey Basin, Offshore Cameroon. J Pet Environ Biotechnol 10: 389. doi: 10.4172/2157-7463.1000389.

Copyright: (c) 2019 Bate BB, et al. This is an open-access article distributed under the terms of the Creative Commons Attribution License, which permits unrestricted use, distribution, and reproduction in any medium, provided the original author and source are credited. 


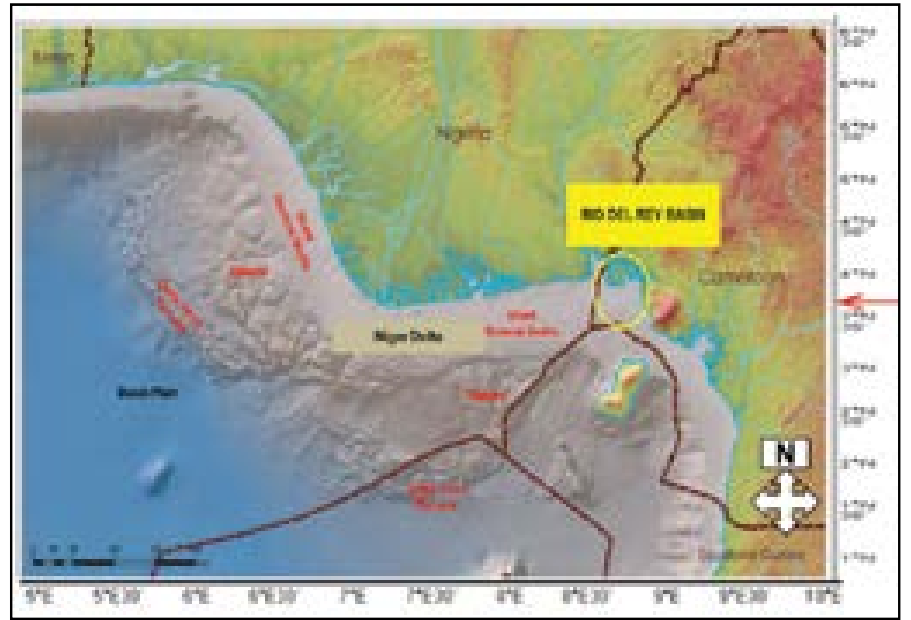

Figure 2: Map showing both the offshore and onshore segments of Rio Del Rey Basin (Modified from Google terrain map).

Despite the high potential of Cameroon's sedimentary basins for significant hydrocarbon reserves, they remain underexplored [9]. Therefore, it is important to review the geology of this basin in order to reveal its tectonic evolution, stratigraphic and structural framework, petroleum systems and hydrocarbon potential this would further highlight its petroliferous nature and call for more exploration activities. Since previous work had mostly been done by the government agencies and remained classified.

\section{Tectonic Evolution}

The tectonic evolution of the RDR Basin, as well as most basins found along the West African coast (Gulf of Guinea), is strongly related to the processes of rifting and drifting that resulted in the opening of the South Atlantic Ocean, hence leading to the separation of the South American plate from the African plate. The three stages marking the tectonic evolution of RDR Basin are:

- Pre-rift stage. It ranges in age from Late Proterozoic to Late Jurassic, characterized by continental deposits of clastic rocks which are Carboniferous to Jurassic in age [10].

- Syn-rift stage. Ranges in age from Late Jurassic to Early Cretaceous, consisting of thick sequences of fluvial and lacustrine deposits.

- Post-rift stage. Its age ranges from Late Cretaceous to Holocene. It constituents younger rocks which are deposited as transgressive units made of shelf clastic and carbonate rocks accompanied by progradational units along the continental margins and as open-ocean water units [9].

\section{Structural Framework}

The structural style of the Niger Delta extends into the Rio Del Rey Basin, with both growth fault and overpressured clay diapir zones being recognizable (Figure 3) [11,12]. Four structural provinces make up the RDR Basin [13]. These include the Cretaceous Onshore province, the Growth Fault province in the north, the Shale Ridge province in the southwest, and the Delta Toe-thrust zone in the south-central area (Figure 4) $[14,15]$. The Rio Del Rey Basin is characterized by three main structural styles from north to south:

- Detachment-based growth fault zone;
- Highly faulted, mobile shale cored domes and ridges;

- Toe thrusts and folds.

Almost all individual hydrocarbon traps are fault-dependent, and lack of sufficient internal seals in sand-rich wave-dominated deltaic sequences can limit the objective window.

Downthrown fault traps in hanging-wall reservoirs are effectively sealed against older prodelta and marine shales and are present in most fields. All large oil fields are located in the dome and ridge province and are potential analogues for similar structures now being explored on the upper slope offshore Nigeria. Marine shales of Paleocene to Eocene are the best quality source rocks identified so far.

\section{Stratigraphy of the RDR Basin}

Short and Stauble reported that the subsurface offshore of RDR Basin has a stratigraphic succession broadly similar to that of the Niger Delta [16] (Figure 5). There is a diachronous succession of pro-delta shales (the Akata Formation), overlain by delta front sands and shales (the Agbada Formation), in turn, overlain by fluvial sands (the Benin Formation). These deposits range in age from Eocene to Recent (Table 1).

\section{Petroleum System}

Petroleum occurs throughout the Agbada Formation in the RDR clastic wedge. Although the distribution of hydrocarbons is complex, there is a general tendency for the ratio of gas to oil to increase eastward within individual depobelts [17].

In the onshore part of the basin, the Agbada Formation has reservoir rocks consisting of sandstones and paralic non-consolidated sand. The depth of burial and depositional environments of these reservoirs are the two main factors controlling the characteristics of the reservoirs. Nevertheless, the major target in deep water are the turbidite sands in the Akata Formation. The eastern portion of the RDR Basin is made up of alternation of sand and shale thus confirming the existence of thick and effective seals.

The Akata Formation constitutes the source rocks consisting of upper prodeltaic marine shales. There is also the presence of possible source shales at the base of the Eocene Agbada Formation [18]. According to Stacher, the organic matter are predominantly

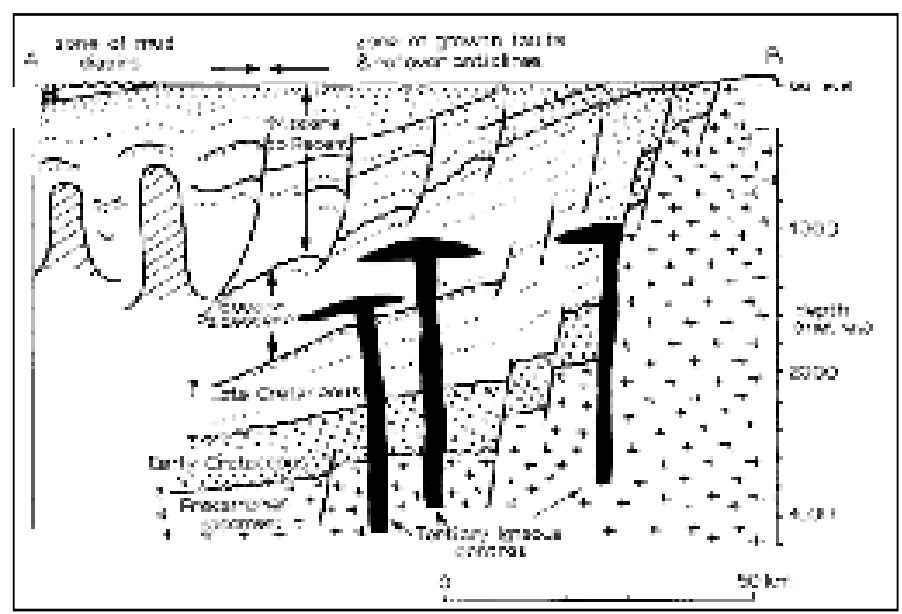

Figure 3: Geologic cross section of the RDR Basin showing the presence of growth faults and clay diapirs $[11,12]$. 


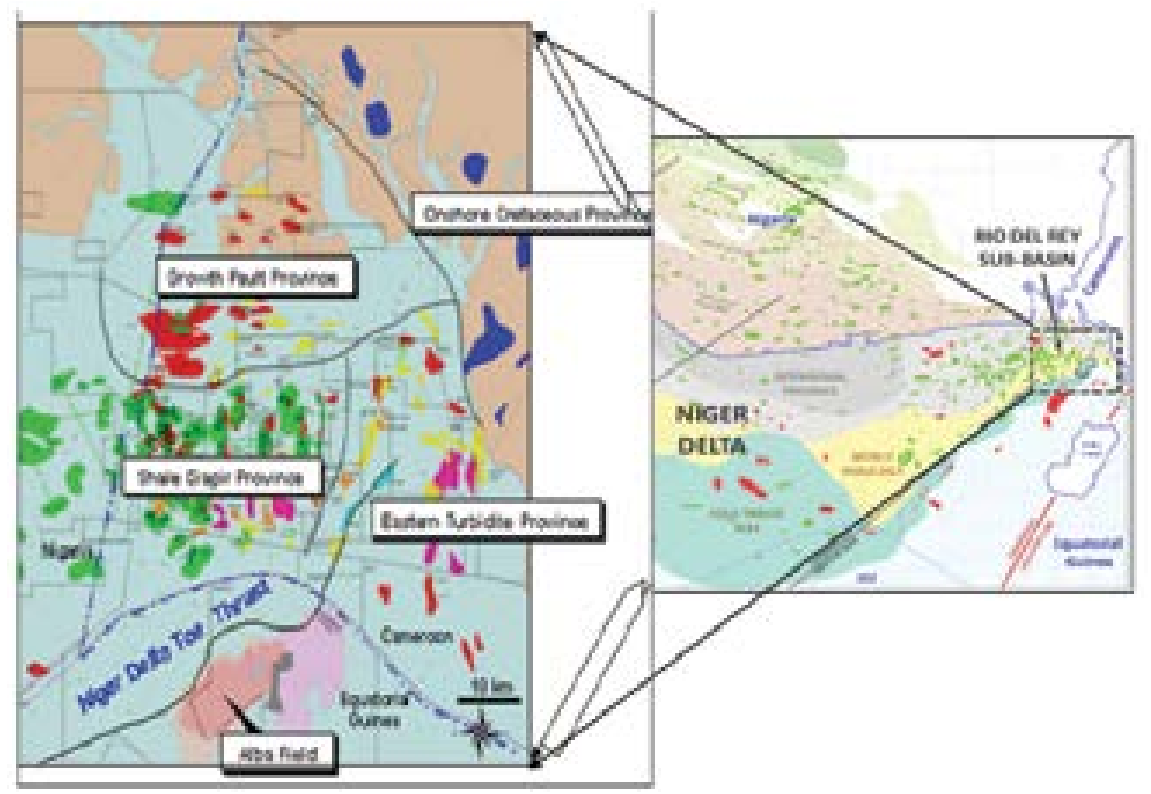

Figure 4: The four provinces shown on the regional structure map of Rio Del Rey Basin $[14,15]$.

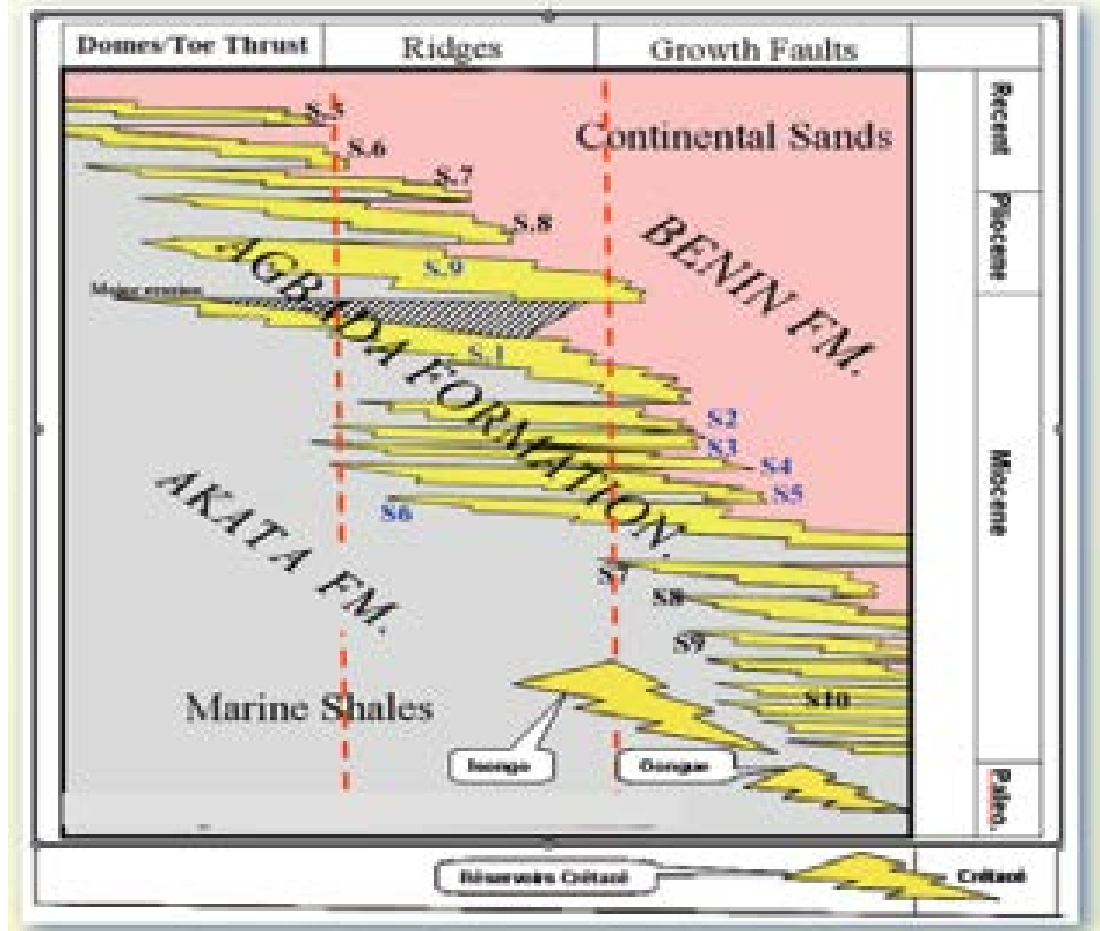

Figure 5: Stratigraphic section of Rio Del Rey Basin, offshore Cameroon [13]

\begin{tabular}{|c|c|c|}
\hline Formations with their respective age range & Lithology & Depositional Environment \\
\hline $\begin{array}{c}\text { Benin } \\
\text { (Ranges in Age from Upper Miocene to Recent) }\end{array}$ & $\begin{array}{l}\text { Made up of massive continental sands with intercalation of rare } \\
\text { shale }\end{array}$ & Alluvial and coastal plain \\
\hline $\begin{array}{c}\text { Agbada } \\
\text { (Ranges in Age from Upper Miocene to Recent) }\end{array}$ & $\begin{array}{c}\text { Consist of Siliciclastic deltaic sequence. Interbeds of sands and silts } \\
\text { designated by 'S' and shale designated by 'M' }\end{array}$ & $\begin{array}{l}\text { Delta front, prodelta, fluvio- } \\
\text { deltaic }\end{array}$ \\
\hline $\begin{array}{c}\text { Akata } \\
\text { (Palaeocene to Recent) }\end{array}$ & $\begin{array}{l}\text { Undercompacted marine shales, local turbiditic sandstones (Nguti, } \\
\text { Isongo, Oongue), channel fill or offshore bar deposits (Etisah, Qua } \\
\text { Iboe, Rubble beds) }\end{array}$ & Prodelta, Deepwater \\
\hline
\end{tabular}

Table 1: The three diachronous formations in the RDR Basin, offshore Cameroon.

of terrestrial origin consisting of Type III/I kerogens (humic to mixed type) [19].

Seals are more efficient in the turbiditic sands. These clays form top seals for some important fields in the eastern portion of the RDR Basin [17]. Structural traps are more common, although there are pinch-outs and turbiditic fan lenses [20]. Studies from Evamy and Haremboure, shows that the development of structural traps was during syn-sedimentary deformation of the Agbada paralic sequence [21]. Hydrocarbon migration in the basin is probably favoured by the presence of minor faults (Figure 6). 


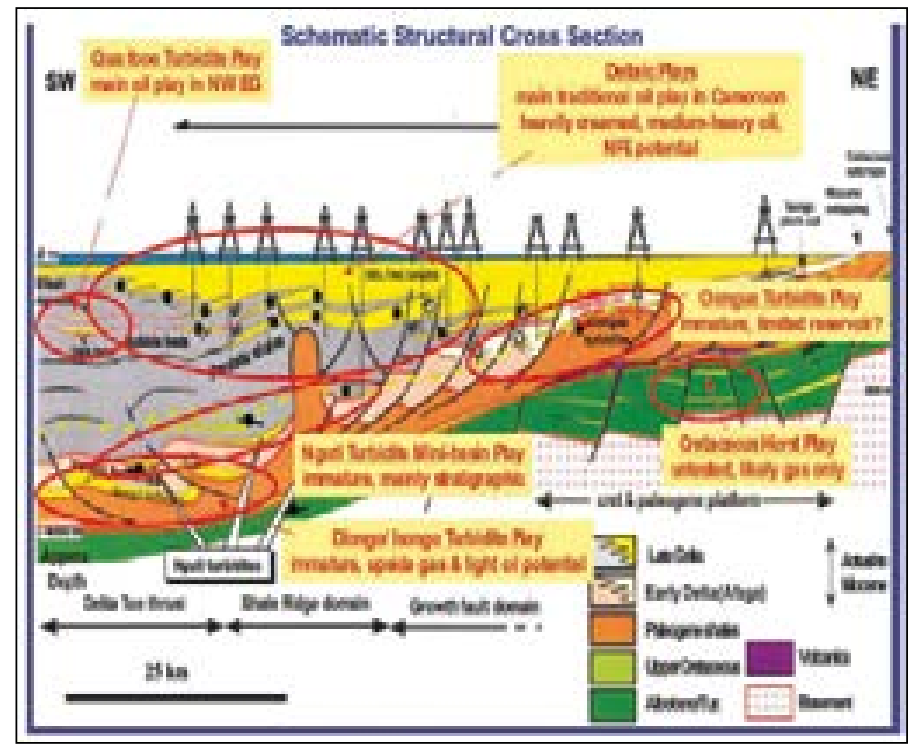

Figure 6: Cross section through the RDR Basin showing traps and plays [13].

Hydrocarbon potential: The hydrocarbon potential is a function of the organic richness, maturity of the source rocks and the kerogen type present in the basin. In the Rio Del Rey basin, the presence of source rocks, anticlinal structures, and faults, favours the generation and trapping of hydrocarbons. The basin consists of mostly sandy reservoirs, which have been proved, explaining the presence of oil fields [22].

Gas of biogenic origin is also present in significant quantity in the basin [7]. The quantity of oil produced from this basin is more than that from the Douala Basin. Report from SNH confirms the discovery of condensate in the Rio Del Rey Basin, Cameroon.

\section{CONCLUSION}

The geology of the Rio Del Rey Basin, offshore Cameroon, features three stages of tectonic evolution: Pre-rift stage (late Proterozoic to Late Jurassic), Syn-rift stage (Late Jurassic to Early Cretaceous) and Post-rift stage (Late Cretaceous to Holocene) with the deposition of about $6000 \mathrm{~m}$ of continental clastic rocks, thick sequences of fluvial and lacustrine rocks, shelf clastic and carbonate rocks. The major tectonic feature (CVL) marks a major change in the tectonic style between the RDR Basin and Douala/Kribi Campo Basin. The stratigraphy of this basin is similar to that of the Niger Delta in Nigeria. Although the basin is smaller than the Douala/ Kribi Campo Basin, it is the most prolific petroleum province in Cameroon.

\section{REFERENCES}

1. Gwanfogbe M, Melingui A. Geography of Cameroon. Macmillan, London. 1983.

2. Mateer NJ, Wycisk P, Jacobs LL, Brunet M, Luger P, Arush MA. Correlation of nonmarine cretaceous strata of Africa and the Middle East. Cretaceous Res. 1992;13:273-318.

3. Fitton JG. The Cameroon line, West Africa:a comparison between oceanic and continental alkaline volcanism. Geological Society London. 1987;30:273-291.

4. Moundi A, Wandji P, Bardintzeff JM, Ménard JJ, Okomo Atouba $\mathrm{LC}$, Mouncherou $\mathrm{OF}$, et al. Les basalt eséocènes à affinité transitionnelle $\mathrm{du}$ plateau Bamoun, témoins d'un reservoir mantellique enrichi sous la ligne volcanique du Cameroun. CR Geoscience. 2007;339:396-406.

5. Edwin AN, Christopher MA, Mathew EN, James CH, Michael AO. Organic petrography and petroleum source rock evaluation of the Cretaceous Mamfe Formation, Mamfe basin, Southwest, Cameroon. Inter J Coal Geology. 2018;202:27-37.

6. Longmore J, Lee J. Africa oil and gas source 2010:Cameroon. 2010;3.

7. Coughlin R, Bement W, Malony W. A petroleum geology of the deltaic sequence, Rio Del Rey, offshore Cameroon. AAPG Search and Discovery. 1993;Article No. 0909904.

8. SNH. Republic of Cameroon. Third Liscencing Round:The Rio Del Rey Basin Basin. 2010;pp:4-8.

9. Brownfield ME, Charpentier RR. Geology and total petroleum systems of the West Central province.7203; West Africa. US Geological Survey, Bulletin 2006.

10. Villemin J, Tarreserence P. Sedimentary basins of Carbon Geology and Oil systems. Am Assoc Petro Geologists Memoir, Tulsa. 1990;pp:117-199.

11. Logar JE. Afrique de l'Ouest. Well Evaluation Conference. Schlumberger, Paris. 1983;p:205.

12. Ala MA, Sally RC. The West African Coastal Basins. Sedimentary Basins of the World. 1997;3:173-186.

13. SNH. Synthèse sur le Bassin du Rio Del Rey et sur le bassin de Douala/Kribi-Campo 2005.

14. Kumar KS. Seismic evidence for fluid migration and gas accumulation in sediment formation beneath the giant Stroregga slide complex. Grip high 3D cube;. Munin Open Res Arc. 2012;pp:24-36.

15. Bellingham P. The structural and stratigraphic development of the Rio Del Rey Basin.Offshore Cameroon;. Implications for play distribution and remaining exploration potential 1970.

16. Short KC, Stauble AJ. Outline of geology of Niger Delta. Am Assoc Pet Geol Bull. 1967;51:761-779.

17. Doust H, Omatsola ME. Niger Delta. In:Edwards JD, Santo-Grossi PA.eds.;, Divergent/passive margin basins, AAPG Memoir 48. Am Assoc Petr Geologists, Tulsa. 1990:239-248.

18. Fozao KF, Fotso L, Lordon AD, Mbeleg M. Hydrocarbon inventory of the eastern part of the Rio Del Rey Basin using Seismic attributes. J Petr Explor Pro Tech. 2018;8:655-665.

19. Stacher P. Present Understanding of the Niger Delta hydrocarbon habitat. Geology of Deltas. 1995;3:257-267.

20. Beka F, Oti MN. The distal offshore Niger Delta:frontier prospects of a mature petroleum province. J Geoscience Geomatics. 1995;6:237-241.

21. Evamy B, Haremboure J, Kame P. Hydrocarbon habitat of Tertiary Niger Delta. Am Assoc Pet Geol. 1978;62:277-298.

22. Nguimbous-Kouoh JJ, Tchutchoua J, Ngos III S, Mbarga TN, Manguelle-Dicoum E. Hydrocarbon Potential of Two Coastal Basins.Cameroon;. Inter J Geoscience. 2018;9:131-147. 